\title{
PEMILIHAN DISTRIBUTOR OLEH CV. SINAR MATAHARI PARIAMAN MENGGUNAKAN METODE ANALYTICAL HIERARCHY PROCESS DAN GOAL PROGRAMMING
}

\author{
FITRIA SARAH, DODI DEVIANTO, BUKTI GINTING \\ Jurusan Matematika, \\ Fakultas Matematika dan Ilmu Pengetahuan Alam, Universitas Andalas, \\ Kampus UNAND Limau Manis Padang, Indonesia, \\ email : fitriaasarah@gmail.com
}

\begin{abstract}
Abstrak. Dalam perindustrian hubungan antara produsen dan konsumen tidak bisa dipisahkan dengan distributor karena distributor memiliki tugas menyalurkan produk yang dihasilkan produsen kepada konsumen. Jika peran distributor kurang optimal maka proses pendistribusian barang kepada konsumen pun kurang maksimal. Penelitian ini bertujuan untuk menyelesaikan kasus pemilihan distributor dengan studi kasus di CV Sinar Matahari Pariaman Sumatera Barat. Metode yang digunakan untuk permasalahan ini yaitu metode Analytical Hierarchy Process untuk pembobotan dan metode Goal programming untuk optimasi. Kriteria dan alternatif distributor ditentukan oleh CV Sinar Matahari dimana terdapat empat kriteria dan lima alternatif distributor dengan bobot kriteria Permodalan (0.066), Kelayakan Gudang (0.548), Armada Pengiriman (0.151) dan Tenaga Kerja (0.236) dengan nilai Consistency Ratio antarkriteria dan semua alternatif $\leq 0.1$. Dari lima alternatif pilihan tersebut diperoleh 1 distributor yang paling direkomendasikan yaitu Kandidat 3 disusul dengan prioritas rekomendasi distributor lainnya yaitu Kandidat 4, 2, 1 dan 5 .
\end{abstract}

Kata Kunci: Analytical hierarchy process, distributor, Goal programming

\section{Pendahuluan}

Kebutuhan masyarakat akan sandang, pangan dan papan semakin meningkat. Oleh karena itu, banyak perusahaan bermunculan untuk memenuhi kebutuhan masyarakat. Perusahaan-perusahaan tersebut memproduksi segala bentuk kebutuhan masyarakat. Namun barang-barang tersebut tidak akan sampai ke konsumen jika sistem pendistribusiannya tidak tepat. Oleh karena itu, perusahaan membutuhkan pihak ketiga sebagai distributor karena sebagian besar perusahaan tidak memiliki kemampuan untuk memasarkan produk dan menguasai pasar di suatu wilayah.

Sebagai salah satu perusahaan yang telah mengirimkan produknya ke berbagai daerah di Sumatera Barat, CV Sinar Matahari yang berada di Kota Pariaman bergerak dalam memproduksi mie kuning kering. Dalam pemasaran produk, CV Sinar Matahari telah bekerja sama dengan beberapa retailer-retailer untuk menjual produknya. Dari beberapa retailer tersebut CV Sinar Matahari akan mengurutkan prioritas distributor berdasarkan kebutuhan perusahaan dalam memasarkan pro- 
duknya di suatu wilayah sesuai dengan kesepakatan.

Oleh karena itu, dalam proses pemilihan distributor manajemen perusahaan CV Sinar Matahari tidak bisa sembarangan mengambil keputusan karena distributor akan memenuhi permintaan pasar dalam suatu wilayah tersebut. CV Sinar Matahari memiliki beberapa kriteria yang harus dipenuhi oleh retailer yang akan menjadi distributor. Kriteria tersebut adalah permodalan, kelayakan gudang, armada pengiriman dan tenaga kerja.

Dalam tulisan ini, kriteria yang ditentukan berupa kriteria kualitatif sehingga pengambilan keputusannya harus konsisten. Oleh karena itu, penulis menggunakan metode Analytical Hierarchy Process (AHP) dan Goal programming. Metode Analytical Hierarchy Process (AHP) digunakan untuk menyelesaikan permasalahan kualitatif menjadi kuantitatif dengan penilaian subjektif dari pengambil keputusan. Penilaian membutuhkan konsistensi atas penaksiran tingkat kepentingan sesuai dengan keinginan atau kepentingan pengambil keputusan. Analytical Hierarchy Process digunakan sebagai pembobotan tingkat kepentingan dari pengukuran kriteria. Nilai prioritas yang telah dibobotkan digunakan sebagai koefisien ke dalam model Goal programming untuk membantu menentukan prioritas distributor yang tepat dan optimal.

\section{Landasan Teori}

\subsection{Analytical Hierarchy Process}

Analytical Hierarchy Process adalah suatu model pendukung keputusan yang akan menguraikan masalah multi faktor atau multi kriteria yang kompleks menjadi suatu hirarki [1]. Dalam menyelesaikan permasalahan dengan metode Analytical Hierarchy Process ada beberapa prinsip yang harus dipahami, diantaranya sebagai berikut [4]:

(1) Dekomposisi (Decomposition). Mendefiniskan masalah dan menentukan solusi yang diinginkan, kemudian menyusun hirarki dari permasalahan yang dihadapi.

(2) Penilaian Komparatif (Comparative Judgement). Menentukan prioritas elemen. Dengan memakai skala rasio 1 sampai 9 maka pengambil keputusan dapat menentukan penilaiannya terhadap kriteria-kriteria dan alternative-alternatif tersebut. Keterangan dari skala angka terdapat pada Gambar 1.

(3) Sintesis Prioritas (Synthesis of Priority). Menentukan prioritas dari elemenelemen kriteria dapat dipandang sebagai bobot/kontribusi elemen tersebut terhadap tujuan pengambilan keputusan. Pada tahap ini dicari bobot dari masingmasing kriteria dan alternatif distributor. Cara menghitung bobot yaitu membuat matriks normalisasi dari matriks perbandingan berpasangan dan mencaru rata-rata tiap barisnya.

(4) Konsistensi Logis (Logical Consistency). Mengukur konsistensi dari setiap matriks perbandingan berpasangan dengan cara mencari $\lambda_{\max }, C I$ dan $C R$.

a. Mencari $\lambda_{\max }$. Membentuk suatu matriks $C$ dimana elemennya merupakan perkalian antara elemen dari kolom pertama matriks perbandingan berpasangan dengan elemen pertama rata-rata baris matriks normalisasi. Dari matriks $C$ tersebut kemudian dicari jumlah tiap barisnya. Kemudian 


\begin{tabular}{|c|c|c|}
\hline Nilai & Definisi & Penjelasan \\
\hline 1 & $\begin{array}{l}\text { Kedua elemen sama } \\
\text { pentingnya }\end{array}$ & $\begin{array}{l}\text { Dua elemen mempunyai } \\
\text { pengaruh yang sama besar }\end{array}$ \\
\hline 3 & $\begin{array}{l}\text { Elemen yang satu sedikit } \\
\text { lebih penting daripada } \\
\text { elemen yanga lainnya }\end{array}$ & $\begin{array}{l}\text { Pengalaman dan penilaian } \\
\text { sedikit menyokong satu } \\
\text { elemen dibandingkan elemen } \\
\text { yang lainnya }\end{array}$ \\
\hline 5 & $\begin{array}{l}\text { Elemen yang satu lebih } \\
\text { penting daripada yang } \\
\text { lainnya }\end{array}$ & $\begin{array}{l}\text { Pengalaman dan penilaian } \\
\text { sangat kuat menyokong satu } \\
\text { elemen dibandingkan elemen } \\
\text { yang lainnya }\end{array}$ \\
\hline 7 & $\begin{array}{c}\text { Satu elemen jelas lebih } \\
\text { mutlak penting daripada } \\
\text { elemen lainnya }\end{array}$ & $\begin{array}{l}\text { Satu elemen yang kuat } \\
\text { disokong dan dominan terlihat } \\
\text { dalam praktek }\end{array}$ \\
\hline 9 & $\begin{array}{l}\text { Satu elemen mutlak } \\
\text { penting daripada elemen } \\
\text { lainnya }\end{array}$ & $\begin{array}{c}\text { Bukti yang mendukung elemen } \\
\text { yang satu terhadap elemen lain } \\
\text { memiliki tingkat penegasan } \\
\text { tertinggi yang mungkin } \\
\text { menguatkan }\end{array}$ \\
\hline $2,4,6,8$ & $\begin{array}{l}\text { Nilai-nilai antara dua } \\
\text { nilai pertimbangan- } \\
\text { pertimbangan yang } \\
\text { berdekatan }\end{array}$ & $\begin{array}{l}\text { Nilai ini diberikan bila ada dua } \\
\text { kompromi di antara } 2 \text { pilihan }\end{array}$ \\
\hline Kebalikan & \multicolumn{2}{|c|}{$\begin{array}{c}\text { Jika untuk aktivitas } i \text { mendapat satu angka dibanding } \\
\text { dengan aktivitas } j \text {, maka } j \text { mempunyai nilai kebalikannya } \\
\text { dibanding dengan } i\end{array}$} \\
\hline
\end{tabular}

Gambar 1. Skala Perbandingan Berpasangan

setiap elemen matriks $T$ dibagi dengan setiap elemen matriks $R$. Dari hasil tersebut kemudian dirata-rata. Rata-rata akhir tersebut merupakan hasil $\lambda_{\max }$. Secara matematis dituliskan sebagai berikut :

$$
\lambda_{\max }=\left(\frac{\sum_{i=1}^{n} \frac{t_{1 i}}{r_{1 i}}}{n}\right)
$$

b. Mencari $C I$

$$
C I=\frac{\left(\lambda_{\max }-n\right)}{(n-1)}
$$

c. Mencari $C R$

$$
C R=\frac{(C I)}{R C}
$$

dengan $\lambda_{\max }$ adalah nilai eigen maksimum, $n$ adalah banyaknya elemen yang dibandingkan, $t_{1 i}$ adalah elemen matriks $\mathrm{T}, r_{1 i}$ adalah elemen matriks $\mathrm{R}, C I$ adalah indeks konsistensi, $C R$ adalah rasio konsistensi dan $R C$ adalah indeks random konsistensi.

Untuk indeks random konsistensi dapat dilihat pada Tabel 1 sedangkan untuk matriks berukuran $1 \times 1$ dan $2 \times 2$ mempunyai inkonsistensi 0 . Jika $\mathrm{CR} \leq$ 0.1 maka tingkat inkonsistensi dapat diterima. 
Tabel 1. Data Ekspektasi Return dan Risiko Saham BUMN dan pasar

\begin{tabular}{|c|c|c|c|c|c|c|c|c|}
\hline UKURAN MATRIKS & $3 \times 3$ & $4 \times 4$ & $5 \times 5$ & $6 \times 6$ & $7 \times 7$ & $8 \times 8$ & $9 \times 9$ & $10 \times 10$ \\
\hline RC & 0.58 & 0.9 & 1.12 & 1.32 & 1.41 & 1.45 & 1.49 & 1.51 \\
\hline
\end{tabular}

\subsection{Penilaian Perbandingan Multi Partisipan}

Metode Analytical Hierarchy Process hanya memerlukan satu jawaban untuk matriks perbandingan. Namun ada kalanya menggunakan penilaian dengan lebih dari 1 partisipan/responden. Hal ini akan menghasilkan pendapat yang berbeda satu sama lain.

Untuk mencari rata-rata menggunakan metode rata-rata geometri (geometric mean). Rata-rata geometri digunakan untuk deret bilangan yang sifatnya rasio dan dapat mengurangi gangguan yang ditimbulkan salah satu bilangan yang terlalu besar atau kecil. Hal ini sesuai dengan penggunaan metode Analytical Hierarchy Process dimana metode Analytical Hierarchy Process digunakan untuk menemukan skala rasio baik dari perbandingan berpasangan yang diskrit maupun kontinu. Perbandingan ini diambil dari ukuran aktual atau dari skala dasar yang mencerminkan kekuatan perasaan dan preferensi relatif [3].

Teori rata-rata geometri menyatakan bahwa jika terdapat $\mathrm{n}$ partisipan yang melakukan perbandingan berpasangan, maka terdapat $\mathrm{n}$ jawaban untuk setiap pasangan. Untuk mendapatkan nilai tertentu dari semua nilai tersebut, masingmasing nilai harus dikalikan satu sama lain kemudian hasil perkalian itu dipangkatkan dengan $1 / n$ [4]. Secara matematis, ditulis sebagai berikut:

$$
G m=\left(Z_{1} Z_{2} Z_{3} \cdots Z_{n}\right)^{1 / n},
$$

dengan $G m$ adalah nilai rata-rata geometris, $Z_{i}$ adalah nilai dari responden ke-i dan $n$ adalah banyaknya responden.

\subsection{Goal programming}

Goal programming merupakan pengembangan dari program linier. Goal programming diperkenalkan oleh Charnes dan Cooper pada awal tahun enam puluhan. Goal programming merupakan salah satu model matematis yang dapat dipergunakan sebagai dasar dalam pengambilan keputusan untuk menganalisis dan membuat solusi persoalan yang melibatkan banyak sasaran sehingga diperoleh solusi yang optimal. Pendekatan dasar Goal programming adalah untuk menetapkan suatu tujuan yang dinyatakan dengan angka tertentu untuk setiap tujuan, merumuskan suatu fungsi tujuan untuk setiap tujuan, dan kemudian mencari penyelesaian yang meminimumkan jumlah (tertimbang) penyimpangan-penyimapangan pada fungsi tujuan. Model umum dari Goal programming di dalam strukturnya adalah sebagai berikut [2]. Fungsi Objektif :

$$
\min =\sum_{i=1}^{m}\left(w_{i}^{+} d_{i}^{+}+w_{i}^{-} d_{i}^{-}\right)
$$


Kendala:

$$
\begin{aligned}
\sum_{i=1}^{m} u_{i j} x_{j}-d_{i}^{+}+d_{i}^{-} & =g_{i} ; j: 1,2,, n \\
\sum_{j=1}^{n} x_{j} & =1
\end{aligned}
$$

dengan $: Z$ adalah jumlah dari bobot variabel deviasi, $w_{i}^{+}, w_{i}^{-}$adalah bobot relatif deviasi ke- $i, d_{i}^{+} d_{i}^{-}$adalah variabel deviasi dari tujuan ke- $i, u_{i j}$ adalah koefisien keputusan ke- $j$ dari tujuan ke- $i, x_{j}$ adalah variabel keputusan ke- $j, g_{i}$ adalah tujuan ke- $i$ atau target nilai.

\section{HASIL DAN PEMBAHASAN}

\subsection{Analytical Hierarchy Process}

Dalam makalah ini data yang digunakan adalah data kuantitatif dan menggunakan data kualitatif. Data kriteria beserta target dari perusahaan terdapat pada Tabel 3. Untuk data kuantitatif yaitu data perkiraan modal dari 5 alternatif terdapat pada Tabel 4. Langkah-langkah penyelesaian analytical hierarchy process yaitu :

(1) Dekomposisi (Decomposition)

Dalam penelitian ini bentuk struktur hirarki seperti Gambar 1. Dalam Gambar 1 terdapat 3 level dimana level 1 merupakan tujuan yang akan dicapai. Level 2 merupakan kriteria-kriteria yang digunakan dalam penilaian memilih distributor, dan level 3 berisi 5 alternatif.

(2) Penilaian Komparatif (Comparative Judgement)

Pada tahap ini dilakukan penilaian terhadap kriteria dan alternative dengan skala angka ditampilkan pada Gambar 2 dan Gambar 3. Penilaian dilakukan oleh 2 responden yaitu Pemilik perusahaan yang merangkup bidang keuangan, dan Kepala Bidang Pemasaran.

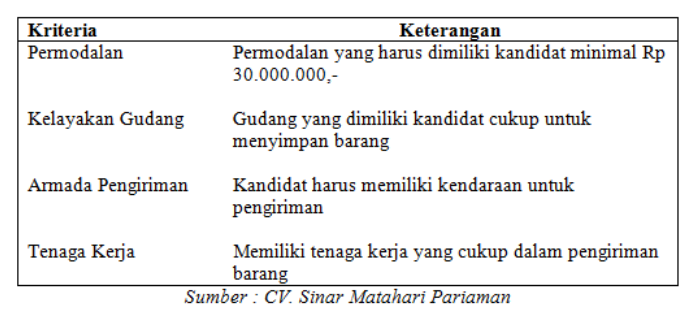

Gambar 2. Kebijakan perusahaan terhadap setiap kriteria

(3) Sintesis Prioritas (Synthesis of Priority)

Untuk memperoleh bobot kriteria dengan menormalisasi matriks perbandingan 


\begin{tabular}{|c|c|c|}
\hline No & Nama & Modal \\
\hline 1 & Kandidat 1 & $\operatorname{Rp~} 10.000 .000$ \\
\hline 2 & Kandidat 2 & $\operatorname{Rp~} 50.000 .000$ \\
\hline 3 & Kandidat 3 & $\operatorname{Rp~} 40.000 .000$ \\
\hline 4 & Kandidat 4 & $\operatorname{Rp~} 9.000 .000$ \\
\hline 5 & Kandidat 5 & $\operatorname{Rp~} 10.000 .000$ \\
\hline \multicolumn{3}{|c|}{ Sumber : CV. Sinar Matahari Pariaman } \\
\hline
\end{tabular}

Gambar 3. Kebijakan perusahaan terhadap setiap kriteria

berpasangan $K$. Matriks $K$ merupakan hasil rata-rata penilaian dari kedua responden terhadap kriteria yang dibutuhkan. Setelah dinormalisasi kemudian tiap baris matriks normalisasi tersebut dirata-rata. Hasil rata-rata tersebut merupakan bobot dari tiap-tiap kriteria.

$$
\begin{gathered}
K=\left[\begin{array}{cccc}
1 & 0.167 & 0.3 & 0.25 \\
6 & 1 & 4 & 3 \\
3 & 0.25 & 1 & 0.5 \\
4 & 0.3 & 2 & 1
\end{array}\right] \\
N=\left[\begin{array}{llll}
0.071 & 0.097 & 0.041 & 0.053 \\
0.429 & 0.582 & 0.548 & 0.632 \\
0.214 & 0.146 & 0.137 & 0.105 \\
0.286 & 0.175 & 0.274 & 0.211
\end{array}\right] \\
R=\left[\begin{array}{l}
0.066 \\
0.548 \\
0.151 \\
0.236
\end{array}\right]
\end{gathered}
$$

Keterangan $: K$ : Matriks perbandingan berpasangan antar kriteria, $N$ : Matriks Normalisasi dari matriks $K, R$ : Hasil perhitungan rata-rata tiap baris matriks $N$.

Hasil bobot masing-masing kriteria ditampilkan pada Tabel 5 dan untuk bobot masing-masing alternative dicari dengan cara yang sama yaitu mendapatkan rata-rata tiap baris matriks normalisasi. Hasil rata-rata tersebut kemudian dikalikan dengan bobot kriteria yang dimaksud. Hasil bobot masingmasing alternatif terhadap kriteria disajikan dalam Tabel 6 .

(4) Konsistensi Logis (Logical Consistency)

Untuk mendapatkan konsistensi dari penilaian terhadap kriteria yaitu dengan cara mendapatkan matriks $\mathrm{C}$ dengan mengalikan elemen kolom pertama dari matriks $\mathrm{K}$ dan baris pertama matriks $\mathrm{R}$ dan seterusnya. Kemudian tiap baris dari matriks $\mathrm{C}$ dijumlahkan.

$$
C=\left[\begin{array}{llll}
0.066 & 0.091 & 0.045 & 0.059 \\
0.394 & 0.548 & 0.602 & 0.709 \\
0.197 & 0.137 & 0.151 & 0.118 \\
0.262 & 0.164 & 0.301 & 0.236
\end{array}\right]
$$




$$
T=\left[\begin{array}{l}
0.261 \\
2.252 \\
0.602 \\
0.964
\end{array}\right]
$$

Setelah diperoleh $R$ dan $T$ selanjutnya mencari $\lambda_{\max }$ dengan persamaan (1). Setelah didapatkan $\lambda_{\max }$ kemudian mencari $C I$ dan $C R$ dengan merujuk ke (2), (3) dengan RC yaitu 0.9

$$
\begin{aligned}
\lambda_{\max } & =\frac{16.18}{4}=4.0443 \\
C I & =\frac{4.0443-4}{3}=0.015 \\
C R & =\frac{0.0148}{0.9}=0.016 .
\end{aligned}
$$

Keterangan: $C$ : matriks perkalian elemen $K$ dan $R, T$ : jumlah tiap baris matrik $C$.

Diperoleh konsistensi dari penilaian antar kriteria yaitu $C R=0.016$. Dengan cara yang sama diperoleh konsistensi matriks rata-rata masing-masing penilaian yaitu :

(a) $C R=0.011$ untuk penilaian alternatif terhadap kriteria permodalan

(b) $C R=0.011$ untuk penilaian alternatif terhadap kriteria kelayakan gudang

(c) $C R=0.008$ untuk penilaian alternatif terhadap kriteria armada pengiriman

(d) $C R=0.025$ untuk penilaian alternatif terhadap kriteria tenaga kerja.

Karena semua penilaian $C R \leq 0.1$ maka penilaian tersebut cukup konsisten.

\subsection{Goal programming}

Pada penelitian ini fungsi tujuan dan fungsi kendala merujuk pada persamaan (5), (6) dan (7). Untuk fungsi tujuannya adalah :

$$
\min Z=0.548 n_{1}+0.236 p_{2}+0.151 p_{3}+0.066 n_{4}
$$

Dan fungsi kendala diprioritaskan urutannya berdasarkan bobot tertinggi dari metode analytical hierarchy process sebagai berikut:

(1) Kendala Kelayakan Gudang

$$
0.03 x_{1}+0.07 x_{2}+0.208 x_{3}+0.208 x_{4}+0.03 x_{5}+n_{1}-p_{1}=1
$$

(2) Kendala Tenaga Kerja

$$
0.043 x_{1}+0.013 x_{2}+0.043 x_{3}+0.123 x_{4}+0.013 x_{5}+n_{2}-p_{2}=1
$$

(3) Kendala Armada Pengiriman

$$
0.017 x_{1}+0.056 x_{2}+0.056 x_{3}+0.01 x_{4}+0.01 x_{5}+n_{3}-p_{3}=1
$$

(4) Kendala Permodalan

$$
10 x_{1}+50 x_{2}+40 x_{3}+9 x_{4}+10 x_{5}+x_{4}-p_{4}=30
$$


(5) Kendala Pemilihan

$$
\sum_{i=1}^{5} x_{i}=1
$$

dengan

$$
\begin{aligned}
x_{i} & : \text { alternatif/kandidat distributor, } i=1,2,3,4,5 \\
n_{j}, p_{j} & : \text { variabel deviasi, } j=1,2,3,4 \\
z & : \text { fungsi tujuan }
\end{aligned}
$$

Persamaan (3.1) sampai (3.5) kemudian diselesaikan dengan bantuan software. Hasil dari software menunjukan bahwa nilai Objective Value yaitu 0.434 dan alternatif yang paling optimal terpilih adalah $x_{3}$. Kemudian nilai Reduced Cost terkecil setelah $x_{3}$ yaitu $x_{4}$ dengan nilai Reduced Costnya 0, nilai Reduced Cost $x_{2}$ yaitu 0.075, nilai Reduced Cost $x_{5}$ dan $x_{1}$ yaitu 0.097. Berdasarkan analisa tersebut, hasil yang paling optimal sebagai prioritas calon distributor adalah Kandidat 3, Kandidat 4, Kandidat 2, Kandidat 5 dan Kandidat 1.

\section{Kesimpulan}

Dengan menggunakan metode Analytical Hierarchy Process dalam pengambilan keputusan calon distributor yang optimal untuk CV Sinar Matahari melalui pengambilan data kualitatif dengan 5 calon distributor dan 4 kriteria dengan bobot yaitu Permodalan (0.066), Kelayakan Gudang (0.548), Armada Pengiriman (0.151) dan Tenaga Kerja (0.236) dimana bobot tertinggi menandakan prioritas urutan kriteria pada calon distributor. Kriteria kelayakan gudang merupakan kriteria terpenting disusul tenaga kerja, armada pengiriman dan permodalan.

Selanjutnya diperoleh nilai Consistency Ratio $(C R)=0.016$ untuk penilaian antar kriteria, $C R=0.011$ untuk penilaian alternatif terhadap kriteria permodalan, $C R=0.011$ untuk penilaian alternatif terhadap kriteria kelayakan gudang, $C R=$ 0.008 untuk penilaian alternatif terhadap kriteria armada pengiriman, $C R=0.025$ untuk penilaian alternatif terhadap kriteria tenaga kerja. Karena semua penilaian $C R \leq 0.1$ maka penilaian tersebut cukup konsisten.

Dengan menggunakan metode Goal programming diperoleh hasil yang optimal jika output yang dihasilkan terpilih prioritas urutan distributor yaitu alternatif $x_{3}$, alternatif $x_{4}$, alternatif $x_{2}$, alternatif $x_{5}$ dan alternatif $x_{1}$.

\section{Daftar Pustaka}

[1] Brodjonegoro, B. 1992. AHP . Departemen Pendidikan dan Kebudayaan Antar Universitas Studi Ekonomi.

[2] Lee, J. (2009). A hybrid approach of Goal programming for weapon systems selection. Computers \& Industrial Engineering Vol 58 Hal 521-527, ITB.

[3] Mulyono, S. 1991. Operations Research. Fakultas Ekonomi Universitas Indonesia.

[4] Saaty, T.L. 1993. Pengambilan keputusan bagi para pemimpin. PT Pustaka Binaman Pressindo, Jakarta. 